\title{
Hidroksiklorokin sülfat kaynaklı plazma hücreli gingivitis: Olgu sunumu
}

\author{
Türkel Hasanzade(0000-0001-8528-7124) ${ }^{\alpha}$, Mehmet Sağlam(0000-0002-2703-2462) ${ }^{\alpha}$
}

Selcuk Dent J, 2020; 7: 334-337 (Doi: 10.15311/selcukdentj.567866)

Başvuru Tarihi: 20 Mayıs 2019 Yayına Kabul Tarihi: 31 Mayıs 2019

\begin{abstract}
öz
Hidroksiklorokin sülfat kaynaklı plazma hücreli gingivitis: Olgu sunumu

Plazma hücreli gingivitis, dişeti bağ dokusunda yoğun plazma hücresi infiltrasyonu, klinik olarak sınırları belirgin eritematöz, ödematöz dişeti ile karakterize olan dişetinin etiyolojisi tam bilinmeyen nadir görülen benign bir durumudur. Dişeti kızarık, yumuşak bazen granüler görünür ve kolay kanar. Plazma hücrel gingivitisin allerjik menşeli olduğu düşünülmektedir ve muhtemelen sakız, dişmacunu ya da çeşitli gıdalardaki bileşenlerle ilişkili olabilir. Maruz kalınan allerjenin kesilmesi ile lezyon iyileşmektedir. Bu olgu sunumunda, 62 yaşındaki bayan hasta dişetlerinde kanama ve kızarıklık nedeni ile kliniğimize başvurdu. Faz I periodontal tedaviden 1 hafta sonra dişetlerinde bariz eritem mevcuttu. Alınan biyopsi örneklerinin histopatolojik analizi sonucu plazma hücreli gingivitis teşhisi kondu. Allerjen olarak plazma hücreli gingivitise neden olan hidroksiklorokin isimli antiromatizmal ilacın kesilmesi sonucu dişetlerinde tam iyileşme gözlendi.
\end{abstract}

\section{ANAHTAR KELIMELER}

Gingivitis, hidroksiklorokin, hipersensivite, plazma hücresi

Plazma hücreli gingivitis, dişetinin nadir görülen, kollajen liflerin arasına kümelenmiş plazma hücrelerinin yoğun infiltratı ile karakterize benign lezyonudur. ${ }^{1}$ Genellikle çeşitli antijenlere, tatlandırıcılara veya baharatlara karşı oluşan aşırı duyarlılık reaksiyonudur. ${ }^{2}$ Bu lezyonun önemi, ciddi gingival inflamasyona, kanamaya neden olabilmesi, diskoid lupus, liken planus, sikatrisyel pemfigoid, HIVgingivitisi ile karıştırılabilmesi ve malignite gibi daha ciddi durumları taklit edebilmesidir. ${ }^{3,4}$ Plazma hücreli gingivitisin etiyolojisi net değildir, fakat plazma hücrelerinin bariz varlığı nedeniyle, birçok yazara göre diş macununda, sakızda, bazı gıdalarda bulunabilecek allerjenlere ve ağız bakım ürünlerine karşı immünolojik bir reaksiyon olduğu düşünülmektedir. Diş macunlarında ve sakızlarda bulunan nane ${ }^{5}$, varsayılan bir allerjendir. Pirofosfatın hoş olmayan tadını maskelemek için genellikle diş macunlarına eklenen sinnamon aldehit, plazma hücreli gingivitisin gelişmesi ile de ilişkilidir. ${ }^{6}$ Bitkisel diş macunu kullanımı ile ilgili vakalar bildirilmiştir. ${ }^{7}$ Bazı biberiye çeşitleri,

\begin{abstract}
Hydroxychloroquine sulphate-induced plasma cell gingivitis: Case report

Plasma cell gingivitis is a rare benign condition of the gingiva of unknown exact etiology characterized by demarcated erythematous and edematous gingiva clinically and a heavy plasma cell infiltration into the gingival connective tissue. The gingiva appears red, friable, and sometimes granular and bleeds easily. Plasma cell gingivitis is thought to be allergic in origin, possibly related to components of chewing gum, dentifrices, or various diet components. Cessation of exposure to the allergen brings resolution of the lesion. In this case report, 62 years old female patient referred to our clinic because of gingival bleeding and erythema. Apparent erythema was still seen in gingiva 1 week after Phase I periodontal treatment. Plasma cell gingivitis was diagnosed after histopathologic analysis of biopsied tissues. Complete gingival healing was observed after cessation of antirheumatic drug named hydroxychloroquine as an allergen causing plasma cell gingivitis.
\end{abstract}

\section{KEYWORDS}

Gingivitis, hydroxychloroquine, hypersensitivity, plasma cell

baharatların $^{8}$ ve khat (Cahta edulis) bitkisinin güçlü plazma hücreli gingivitise neden olan önemli faktörler olabileceği öne sürülmüştür. ${ }^{9}$ Bununla birlikte, patogenezde birden fazla etiyolojik faktörün rol oynaması muhtemeldir. Allerjenlerin neden olduğu lezyonlardan başka, plazma hücreli gingivitisin neoplastik bir lezyonu veya idiopatik nedenlerle ortaya çıkan lezyonlar olabilir. Klinik olarak yapışık ve marjinal dişetinde diffüz kızarıklık ve şişlikle karakterizedir ve genellikle mukogingival sınıra kadar ilerler. ${ }^{10}$ Asemptomatik olmakla birlikte bazı kişilerde kaşıntı ve yanma hissiyle karakterize semptomlar gözlenebilir. ${ }^{11}$ Plazma hücreli gingivitisin kadınlarda daha sık görüldüğü bildirilmiştir. ${ }^{10}$ Maksillada görülme sıklığı mandibulaya oranla daha fazladır. ${ }^{9}$

Hidroksiklorokin sülfat romatoid artrit, sistemik lupus eritematozus gibi birçok otoimmün hastalı̆ı̆ın tedavisinde yaygın olarak kullanılmaktadır. ${ }^{12} \mathrm{Bu}$ ilacı kullananlarda yan etki olarak deri reaksiyonları geliştiği rapor edilmiştir. ${ }^{13,14}$

\footnotetext{
${ }^{\alpha}$ İzmir Kâtip Çelebi Üniversitesi Diş Hekimliği Fakültesi Periodontoloji Anabilim Dalı, İzmir
} 
Tek başına periodontal tedavi ve plak kontrolü bu hastalığın tedavisinde etkili olmayabilir. Etiyolojik ajan tanımlanmalı ve bu madde kullanımdan kaldırılmalıdır. ${ }^{15}$ $\mathrm{Bu}$ olgu sunumunda romatoid artrit tedavisinde kullanılan hidroksiklorokin sülfat maddesine karşı gelişen plazma hücreli gingivitis rapor edilmektedir. Literatürde daha önce bu maddeye karşı gelişen plazma hücreli gingivitis oluşumu gösterilmemiştir.

\section{OLGU SUNUMU}

62 yaşında bayan hasta dişeti kanaması, ağız kokusu ve dişetlerinde yanma hissi şikayeti ile İzmir Kâtip Çelebi Üniversitesi Diş Hekimliği Fakültesi Periodontoloji Anabilim Dalı kliniğine başvurmuştur. Alınan anamnezde hastanın romatoid artrite bağlı hidroksiklorokin sülfat (Plaquenil 200 mg, Sanofi Synthelabo Limited, Fawdon / Ingiltere) kullandığı öğrenildi. Yapılan klinik muayenede ağız hijyeninin yetersiz olduğu, üst çenesindeki ön dişler bölgesindeki dişetinde ödem, hiperemi ve periodontal sond ile yapılan hafif bir müdahalede kanama tespit edilmiştir (Resim 1).

Yapılan intraoral muayenede Nikolsky belirtisi negatif olup, herhangi bir kütanöz lezyon gözlenmemiştir. Hastanın ilk seansta hijyenik olmayan restorasyonlarının çıkarılmasına karar verilmiş, diş yüzeyi temizliği uygulanmış ve oral hijyeni eğitimi verilmiştir.

Tedaviden 1 hafta sonra ödemin azaldığı ama dişetlerinin hala eritematöz olduğu ve dişetlerindeki eritemin, plak ve diştaşı miktarından bağımsız olduğu gözlendi (Resim 2). Bu durumda hastadan biyopsi alınmasına karar verildi ve ayrıca hastadan hematolojik testler de istendi. Hematolojik testler sonrası parametrelerin normal sınırlar içinde olduğu öğrenildi. Biyopsi örneği 11-21 nolu dişler arasından, sağlıklı dokuları da kapsayacak şekilde eksize edilerek alındı. Eksize edilen bölgeye gingivoplasti işlemi uygulandı. Biyopsi örneği, \%10'luk formalin barındıran şişe içinde histopatolojik inceleme için laboratuvara gönderildi. Histopatolojik incelemede epitelde incelme, altta kalan bağ dokusundaysa eritrositlerin oluşturduğu hemorajik alan ve plazma hücrelerinin çoğunluğunu oluşturduğu kronik enflamatuar hücre infiltrasyonu gözlendi (Resim 3). Teşhis koyulduktan sonra altta yatabilecek allerjik durumu elemek için hastanın kullandığı diş macununun bitkisel içerikli olup olmadığı soruldu. Hastanın bitkisel içerikli diş macunu kullanmadığı öğrenildi. Hastaya ayrıca tarçın ve kırmızıbiber gibi baharatlar tüketmemesi ve sakız çiğneme alışkanlığı varsa bırakması söylendi.

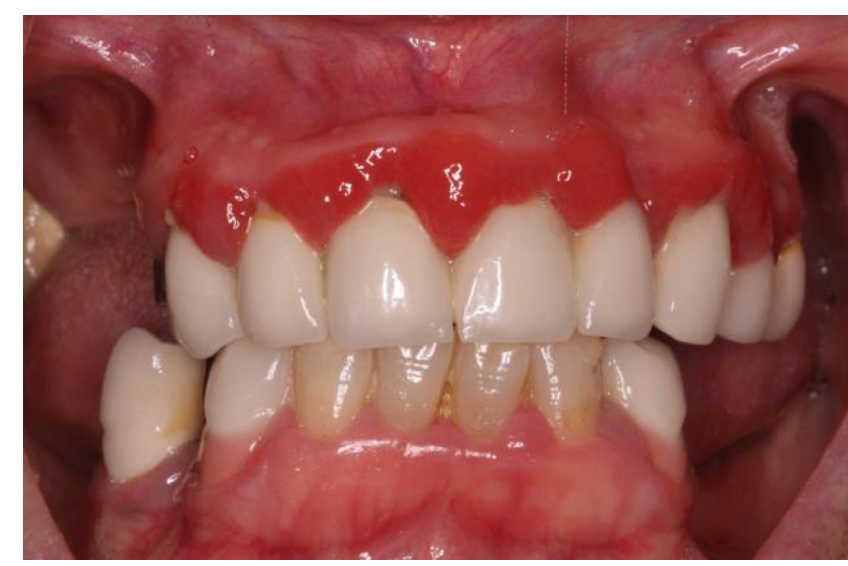

Resim 1.

Tedavi öncesi klinik görünüm

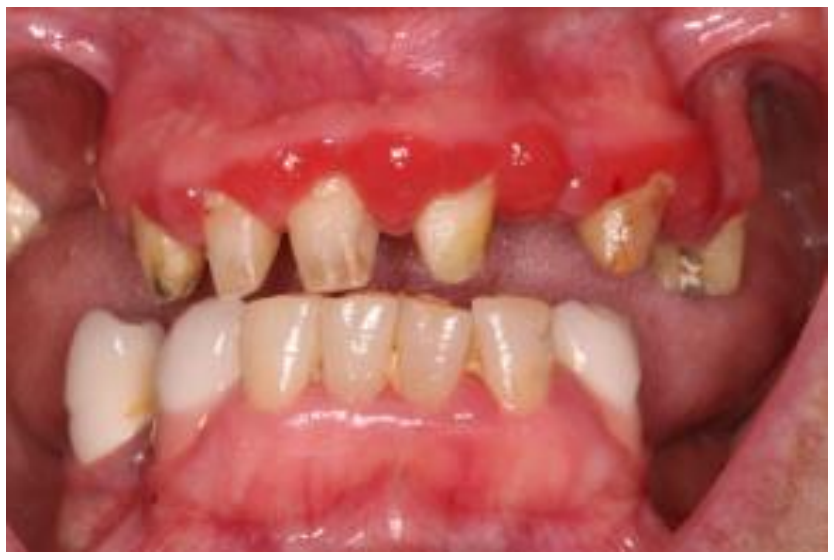

Resim 2.

Periodontal tedaviden 1 hafta sonra klinik görünüm

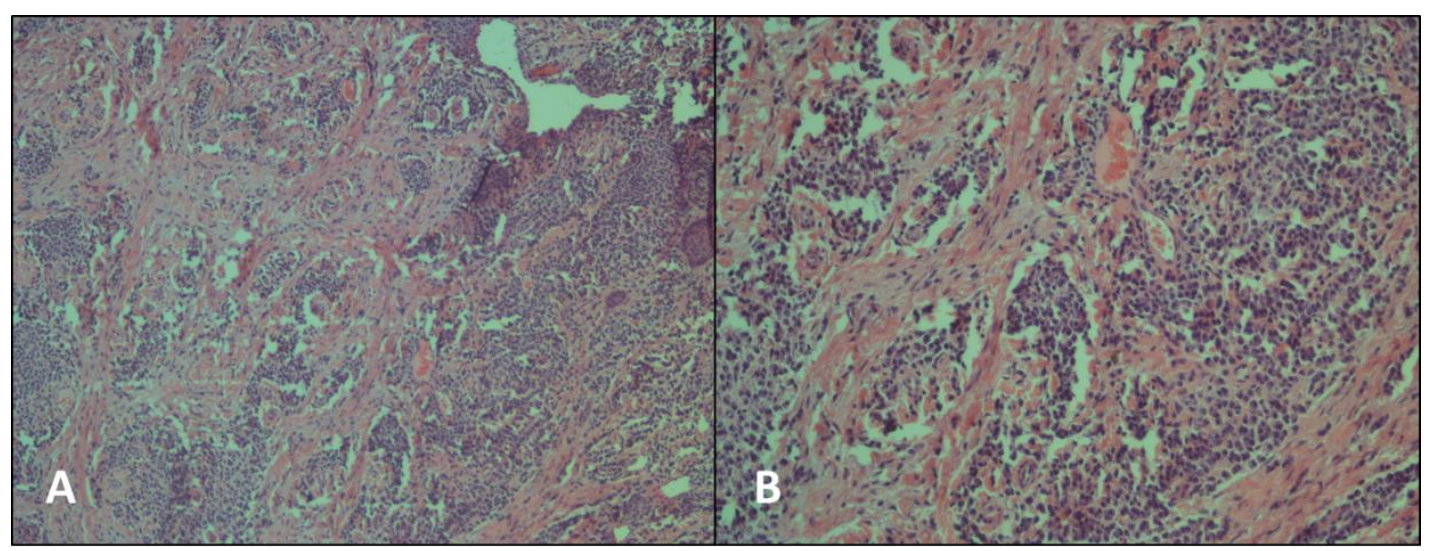

Resim 3.

Biyopsi örneğinin histopatolojik 1şık mikroskobu görüntüsü A-100x B- 400X 
İki hafta sonraki değerlendirmede dişetindeki eritemin azalmadığı gözlendi. Hastanın kullanığı hidroksiklorokinin sülfatın prospektüsünde allerjik reaksiyonlara neden olabileceği belirtildiği için, bu ilacın plazma hücreli gingivitise neden olabileceği düşünülmüş ve Ege Üniversitesi Tıp Fakültesi Romatoloji bölümüyle yapılan konsültasyon sonrası ilacın dozunun yarıya indirilmesine karar verilmiştir. İki hafta sonraki yeniden değerlendirmede dişetindeki eritematöz alanın büyük miktarda azaldığı gözlendiği için hastanın ilacının değiştirilmesine karar verildi. Tüm bu süreç içerisinde ilgili bölgedeki oral hijyenin iyi bir şekilde yapılması için hastaya herhangi geçici bir protetik restorasyon yapılmadı. Hastanın 1 ay sonraki muayenesinde dişetlerindeki eritemin tamamen iyileştiği gözlenince, hastaya yeni protetik restorasyonların yapılmasına karar verildi. Hastanın daha sonraki 1 senelik takip kontrollerinde eritematöz alanın tamamen iyileştiği, dişetinin sağlıklı durumda olduğu gözlenmiştir (Resim 4A, Resim 4B).

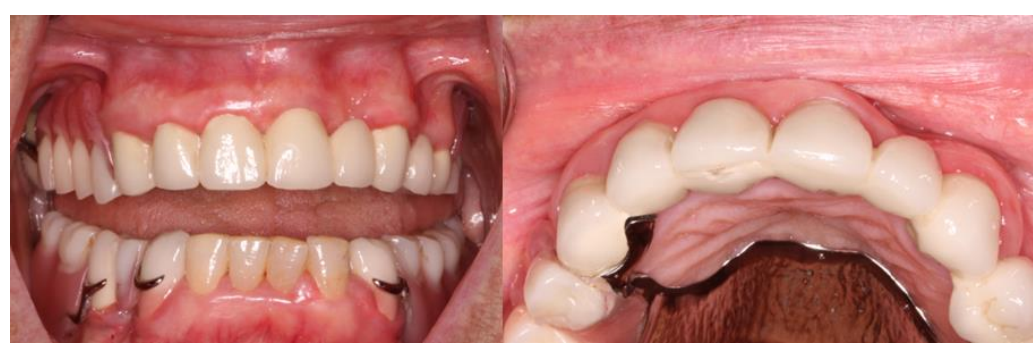

Resim 4.

Hastanın 1 yıllık takibinde klinik görünüm

\section{TARTIŞMA}

Plazma hücreli gingivitis, dişetlerinde aşırı duyarlılık reaksiyonu ile karakterize nadir rastlanan bir durumdur. Plazma hücreli gingivitis aynı zamanda idiopatik gingivostomatit, atipik gingivostomatit, allerjik gingivostomatit, plazma hücreli gingivostomatit, yumuşak doku plazmasitozisi, stomatitis venenata ve irritan kontak stomatiti olarak da bilinmektedir. ${ }^{10}$ Ağız içi lezyonlar genelde diskoid lupus, liken planus, sikatrisyel pemfigoid, HIV-gingivitisi, lösemi ve myeloma lezyonları ile karışıırılabilir. Bu yüzden plazma hücreli gingivitisin tanısında klinik ve histopatolojik muayeneye ek olarak hematolojik testlere de intiyaç vardır. ${ }^{10}$

Plazma hücreli gingivitisin histopatolojik olarak ayırıcı tanısında pemfigus, liken planus, lösemi, plazma sitoma ve myelom düşünülmelidir. ${ }^{1}$ Deri lezyonlarının olmaması, Nikolsky işaretinin negatif olması ve biyopsi sonucunun değerlendirilmesi bu hastalıkların elimine edilmesi açısından önemlidir. Atipik plazma hücrelerinin yokluğu, multipl miyelom ve plazma sitoma gibi maligniteleri ekarte etmek için incelenmelidir. ${ }^{16}$ Hematolojik testlerin normal aralıklarda olması lösemi gibi kan hastalıklarının elimine edilmesi için gerekli tetkiklerdir.

Plazma hücreli gingivitisin ön tanısında en önemli bulgu, konvansiyonel periodontal tedaviye cevap vermeyen dişeti sorunlarıdır ve bu durumda biyopsi alınması gerekmektedir. ${ }^{8}$ Histopatolojik incelemede epitelin altında kalan bağ dokusunda yoğun plazma hücresi infiltrasyonu görülür. ${ }^{5}$ Mevcut vakada faz 1 periodontal tedavi sonrası iyileşmeyen ve plaktan bağımsız lezyonların varlığı, plazma hücreli gingivitis ön tanısını düşündürmüştür.
Plazma hücreli gingivitis lezyonlardaki yoğun plazma hücresi varlığını göz önünde bulundurarak kırmızıbiber, tarçın, zencefil gibi baharatlar, nane, tarçın içerikli diş macunu veya sakızlar gibi allerjenlere karşı immünolojik bir reaksiyon olduğu düşünülmeli ve bu etkenler elimine edilmelidir. . $, 6,8,17$

$\mathrm{Bu}$ olgu sunumunda romatoid artrit tedavisinde kullanılan hidroksiklorokin sülfat maddesinin plazma hücreli gingivitis gelişiminde etkili olduğu görülmüştür. llacın prospektüsünde allerjik reaksiyonlara neden olabileceği belirtildiğinden ve plazma hücreli gingivitisin de allerjik reaksiyon olduğu göz önünde bulunarak bu ilacın plazma hücreli gingivitise neden olabileceği düşünülmüştür. $\mathrm{Bu}$ olgu sunumunda, teşhiste kullanılan histopatolojik incelemelerde sadece hematoksilen-eosin ile boyalı kesitlerde plazma hücrelerinin yoğun infiltrasyonu göz önüne alınmıştır. İlgili etken madde için immünohistokimyasal boyama işlemleri yapılmamıştır.

Klorokin ve hidroksiklorokin antimalaryal etkilerinin yanı sıra romatoid artrit, sistemik lupus eritematozus gibi birçok romatizmal hastalığın tedavisinde yaygın olarak kullanılan, 4 aminokinolin türevi bileşiklerdir. ${ }^{18}$ Sıklıkla iyi tolere edilen antimalaryal ilaçlar deride kaşıntı, psoriasis alevlenmesi, ürtikeryal, morbiliform veya likenoid ilaç erüpsiyonları, alopesi, alerjik kontak dermatit ve Steven Johnson sendromu benzeri döküntü gibi yan etkilere neden olabilmektedir. ${ }^{19}$

Yapılan literatür taramalarında daha önce hidroksiklorokin sülfat maddesine karşı gelişen plazma hücreli gingivitisin rapor edilmediği gözlendi. Bu yüzden bu vaka, konvansiyonel tedaviye cevap vermeyen dişeti hastalıklarında tanıya ulaşmak için kapsamlı anamnez, muayene ve uygun tanı testlerinin önemini göstermektedir. 


\section{KAYNAKLAR}

1. Anil S. Plasma cell gingivitis among herbal toothpaste users: a report of three cases. J Contemp Dent Pract 2007; 8: 60-6.

2. Patanwala A, Fisher, E.W. ,Chapple, L.L.C. Plasma Cell Gingivitis Affecting the Gingiva, Palatal Mucosa and Laryngael Cords. Perio 2006; 3: 123-8.

3. Poswillo D. Plasmacytosis of the gingiva. $\mathrm{Br} J$ Oral Surg 1968; 5: 194-202.

4. Ababneh KT. Biopsied gingival lesions in northern Jordanians: A retrospective analysis over 10 years. Int J Periodontics Restorative Dent 2006; 26: 387-93.

5. Gargiulo AV, Ladone JA, Ladone PA, Toto PD. Case report: plasma cell gingivitis A. CDS Rev 1995; 88: 22 3.

6. Lamey PJ, Lewis MA, Rees TD, Fowler C, Binnie WH, Forsyth $A$. Sensitivity reaction to the cinnamonaldehyde component of toothpaste. Br Dent J 1990; 168: 115-8.

7. Macleod RI, Ellis JE. Plasma cell gingivitis related to the use of herbal toothpaste. Br Dent J 1989; 166: 375-6.

8. Serio FG, Siegel MA, Slade BE. Plasma cell gingivitis of unusual origin. A case report. J Periodontol 1991; 62: 390-3.

9. Marker P, Krogdahl A. Plasma cell gingivitis apparently related to the use of khat: report of a case. Br Dent J 2002; 192: 311-3.

10.Lamdari N, Pradhan S. Plasma cell gingivitis: a case report. JNMA J Nepal Med Assoc 2012; 52: 85-7.

11. Hedin CA, Karpe B, Larsson A. Plasma-cell gingivitis in children and adults. A clinical and histological description. Swed Dent J 1994; 18: 117-24.

12.Fox RI. Mechanism of action of hydroxychloroquine as an antirheumatic drug. Semin Arthritis Rheum 1993; 23: 82-91.

13. Woo TY, Callen JP, Voorhees JJ, Bickers DR, Hanno R, Hawkins C. Cutaneous lesions of dermatomyositis are improved by hydroxychloroquine. J Am Acad Dermatol 1984; 10: 592-600.

14. Pelle MT, Callen JP. Adverse cutaneous reactions to hydroxychloroquine are more common in patients with dermatomyositis than in patients with cutaneous lupus erythematosus. Arch Dermatol 2002; 138: 1231 3; discussion 1233.

15.Sollecito TP, Greenberg MS. Plasma cell gingivitis. Report of two cases. Oral Surg Oral Med Oral Pathol 1992; 73: 690-3.

16.Palmer RM, Eveson JW. Plasma-cell gingivitis. Oral Surg Oral Med Oral Pathol 1981; 51: 187-9.

17.Abhishek K, Rashmi J. Plasma cell gingivitis associated with inflammatory chelitis: a report on a rare case. Ethiop J Health Sci 2013; 23: 183-7.
18.Keskin ED, Seçkin, Ü., Bodur, H., Özcan, M., İkincioğulları, A. Ototoxicity due to antimalarial therapy in patients with rheumatoid arthritis: Two case reports. . Turkish Journal of Physical Medicine and Rehabilitation 2008;54 (1):27-29.

19. Melikoglu MA, Melikoglu M, Gurbuz U, Budak BS, Kacar C. Hydroxychloroquine-induced hyperpigmentation: a case report. J Clin Pharm Ther 2008;33:699-701.

Yazışma Adresi:

Doç. Dr. Mehmet SAĞLAM

İzmir Kâtip Çelebi Üniversitesi

Diş Hekimliği Fakültesi, Periodontoloji AD

Aydınlık Evler Mahallesi, Cemil Meriç Caddesi

6780 Sokak. No:48

35640, Çiğli, İzmir

Tel : +905303249948

E-Posta: dtmehmetsaglam@gmail.com 